NBER WORKING PAPER SERIES

\title{
A PRIMER ON THE ECONOMICS OF PRESCRIPTION PHARMACEUTICAL PRICING IN HEALTH INSURANCE MARKETS
}

\author{
Ernst R. Berndt \\ Thomas G. McGuire \\ Joseph P. Newhouse \\ Working Paper 16879 \\ http://www.nber.org/papers/w16879
}

\author{
NATIONAL BUREAU OF ECONOMIC RESEARCH \\ 1050 Massachusetts Avenue \\ Cambridge, MA 02138 \\ March 2011
}

We have benefited from discussions with Richard G. Frank, Frank McCauley, Mark V. Pauly, Robert S. Pindyck and Fiona Scott Morton, but we are solely responsible for the views expressed herein. This research has not been sponsored. The views expressed herein are those of the authors and do not necessarily reflect the views of the National Bureau of Economic Research.

NBER working papers are circulated for discussion and comment purposes. They have not been peerreviewed or been subject to the review by the NBER Board of Directors that accompanies official NBER publications.

(C) 2011 by Ernst R. Berndt, Thomas G. McGuire, and Joseph P. Newhouse. All rights reserved. Short sections of text, not to exceed two paragraphs, may be quoted without explicit permission provided that full credit, including $(\mathcal{C}$ notice, is given to the source. 
A Primer on the Economics of Prescription Pharmaceutical Pricing in Health Insurance Markets Ernst R. Berndt, Thomas G. McGuire, and Joseph P. Newhouse

NBER Working Paper No. 16879

March 2011

JEL No. D4,I11,L12,L13,L65

\section{ABSTRACT}

The pricing of medical products and services in the U.S. is notoriously complex. In health care, supply prices (those received by the manufacturer) are distinct from demand prices (those paid by the patient) due to health insurance. The insurer, in designing the benefit, decides what prices patients pay out-of-pocket for drugs and other products. In this primer we characterize cost and supply conditions in markets for generic and branded drugs, and apply basic tools of microeconomics to describe how an insurer, acting on behalf of its enrollees, would set demand prices for drugs. Importantly, we show how the market structure on the supply side, characterized alternatively by monopoly (unique brands), Bertrand differentiated product markets (therapeutic competition), and competition (generics), influences the insurer's choices about demand prices. This perspective sheds light on the choice of coinsurance versus copayments, the structure of tiered formularies, and developments in the retail market.

Ernst R. Berndt

MIT Sloan School of Management

100 Main Street, E62-518

Cambridge, MA 02142

and NBER

eberndt@mit.edu

Thomas G. McGuire

Department of Health Care Policy

Harvard Medical School

180 Longwood Avenue

Boston, MA 02115-5899

mcguire@hcp.med.harvard.edu
Joseph P. Newhouse

Division of Health Policy Research and Education

Harvard University

180 Longwood Avenue

Boston, MA 02115-5899

and NBER

newhouse@hcp.med.harvard.edu 


\section{A PRIMER ON THE ECONOMICS OF PRESCRIPTION PHARMACEUTICAL PRICING}

IN HEALTH INSURANCE MARKETS

Ernst R. Berndt, MIT Sloan School of Management and NBER

Thomas G. McGuire, Harvard Medical School

Joseph P. Newhouse, Harvard University and NBER

\section{INTRODUCTION}

The pricing of medical products and services in the U.S. is notoriously complex. This entangled maze likely reflects a confluence of factors: less than universal insurance coverage; heterogeneous buying power of public and private purchasers; federal regulations favoring some public purchasers; the presence of various coinsurance and copayment schemes; the licensing and certification of providers and prescribers; and the impact of patent protection and marketing exclusivity provisions. One root cause of the complexity is the intermediation of insurance and other third party payers. Supply prices - those paid to manufacturers -- are set in markets or by negotiation. Demand prices - those paid by patients at the time they buy medical services or products -- are specified as part of the insurance contract for the great majority of the American population that has health care and drug insurance.

Markets push insurers to set demand prices in a way that maximizes the value of insurance to potential enrollees. There are thus two sets of interacting forces, those operating around supply prices and those operating around demand prices, that determine what the consumer-patient sees in a health insurance contract with respect to medical services or products. Here we focus on coverage of prescription drugs, an increasingly important share of 
health care from the standpoint of both benefits and costs, and one that has recently been a main area of change in health insurance.

Some aspects of demand-side pricing for prescription drugs are difficult to understand, or at least fit poorly within standard frameworks for study of health insurance. Although pharmaceuticals are not mentioned explicitly, readers of the November 21, 2010 Dilbert comic strip may well have thought that Dilbert caricaturist Scott Adams was referring to pharmaceuticals when he parodied "confusopoly" pricing: ${ }^{1}$
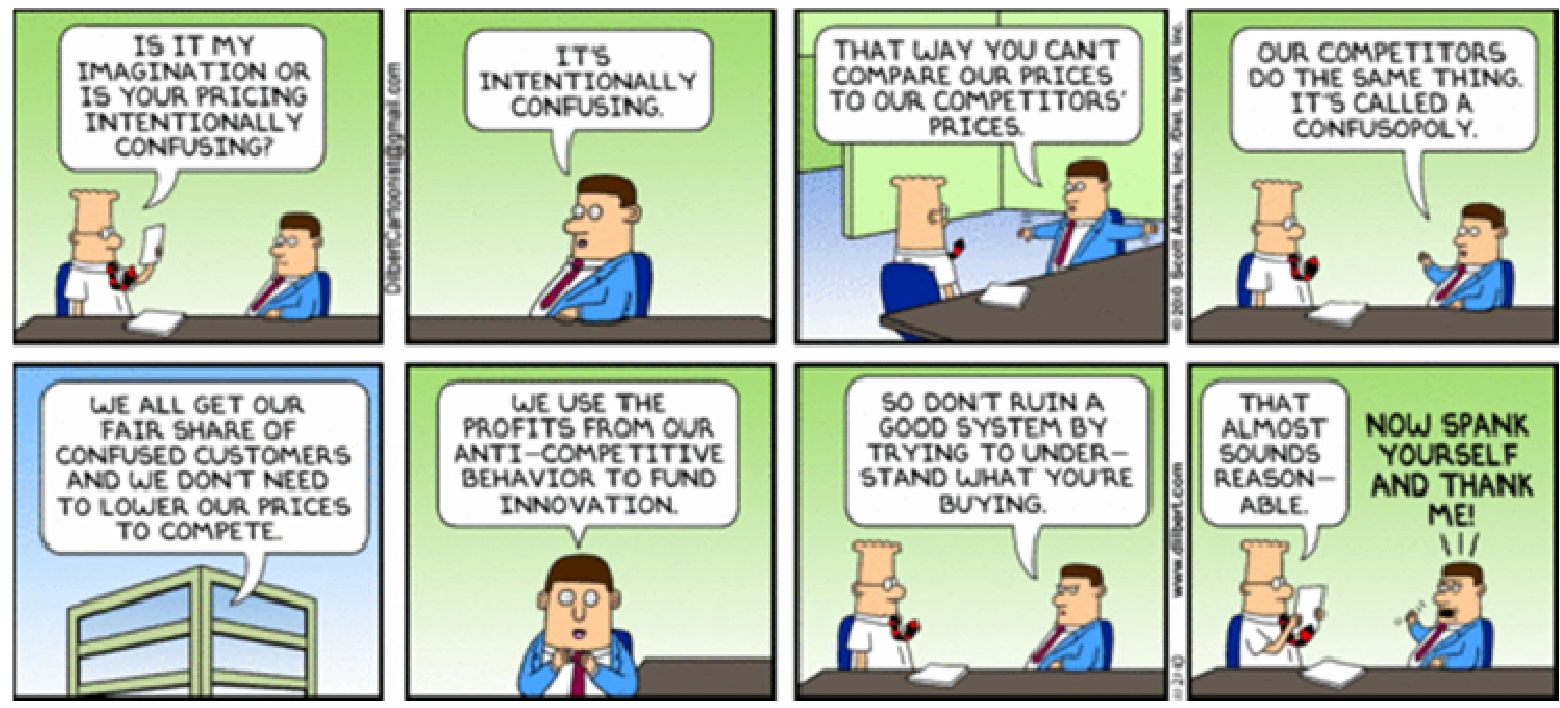

In this primer we provide an analytical framework to help unravel the "confusopoly" pricing of prescription pharmaceuticals. ${ }^{2}$ Textbooks in microeconomic theory typically introduce perfectly competitive markets, then consider the case of pure monopolies, and finally turn to the more complex differentiated product and oligopoly market paradigms. Here we follow a different sequence and begin with the drug market case that approximates a monopoly -- a unique, patent-protected pharmaceutical product that has no close substitutes. Then we turn to the more common case of many products with patent protection that compete with imperfect substitutes. For this case we employ the tools of Bertrand differentiated product 
pricing. Finally, we take up markets for generic, off-patent drugs. From the pharmaceutical manufacturer's view the generic market can be characterized as approximately competitive, but at the retail level this market shares some of the characteristics of the manufacturing market with imperfect substitutes. In all cases, our main intention is to describe how the supply side of the market influences how a profit maximizing insurer sets coverage for these products. Our analysis applies to the American market; regulation of supply-side pricing is more common in other countries, and the consequences for demand-side pricing that we derive here may not readily apply.

Our analysis tries to answer the question of why existing pricing institutions and arrangements have emerged; we do not attempt to be normative. Normative analyses in economics are typically based on maximizing the welfare of a representative consumer (consumers' surplus) plus the economic profits of the supplier (producers' surplus). Demand curves are a critical tool in such welfare analyses, since when consumers are informed and make rational decisions, the demand curve can be interpreted as a marginal benefit schedule. Given the many complexities in health care product markets involving insurance and moral hazard, asymmetric information, patient heterogeneity, price regulation, adverse selection, and physician agency issues, among others, in health care demand curves may not convey marginal benefits.

We assume insurers maximize profits, implying that they seek to lower procurement prices for drugs for their customers given the drugs on the market at each point in time. ${ }^{3}$ We assume insurers ignore any dynamic issues of how their decisions affect incentives for drug 
development. ${ }^{4}$ Since there are many insurers in the U.S. market, this latter assumption is a weak one. ${ }^{5}$

Before turning to our analysis, we note that the production function for new drugs involves substantial upfront costs for research and regulatory approval to market the drug; because we are concerned with the pricing of drugs once they reach the market, we treat these costs as fixed or sunk. Actual manufacturing costs for most small molecule drugs tend to be modest. In addition to the costs of research and regulatory approval and manufacturing, manufacturers of brand drugs also incur substantial marketing costs, but these do not much vary for modest changes in the quantity of drug produced. ${ }^{6}$

\section{MARKETS FOR DRUGS WITH NO CLOSE SUBSTITUTES: THE MONOPOLY PARADIGM}

We begin with the market for a truly unique drug having no close substitutes, i.e., a monopoly product. Any drug that is a major clinical advance will fit this model until a competitor drug appears. For example, for several years after Viagra (sildenafil) was introduced in the U.S. market in 1997, there was no other drug approved for treatment of erectile dysfunction. Another example is Gleevec (imatinib mesylate), launched in 2001 by Novartis after being approved by the FDA for the treatment of a rare cancer -- patients with Philadelphia chromosome positive chronic myeloid leukemia. For several years Gleevec remained the only approved drug in the U.S. for that frequently fatal cancer. Patents maintained the monopoly for both of these drugs, and in each case we can analyze the manufacturer's pricing behavior using standard price theory. Notably, even though each drug is a unique product, its demand curve slopes downward, i.e., quantity demanded increases with reductions in price. The reward of selling more gives even a monopolist a reason to lower price. When buying drugs from a 
monopolist, the insurer can use this incentive to restrain monopoly pricing. As a benchmark, we first consider the case with no drug insurance, and then introduce drug benefit insurance with patient cost sharing. To keep matters simple, we will assume that everyone in the market is insured. ${ }^{7}$ As we will show, the form of cost sharing employed by the insurer affects pricing incentives faced by the monopolist.

We illustrate this case with a linear inverse demand equation of the form:

$$
p=a-b q
$$

where $a$ and $b$ are each parameters greater than zero, $p$ is price, and $q$ is quantity. Our conclusions, however, do not depend on linearity. We hold factors other than q that affect the inverse demand curve as fixed, and subsume their impact in the constant term a. Let total costs TC of production and distribution be the sum of a component independent of output, the fixed cost c, and a constant marginal cost, $d$ :

$$
\mathrm{TC}=\mathrm{c}+\mathrm{dq} \text {, where } \mathrm{c}, \mathrm{d}>0 \text {. }
$$

Profits equal revenues minus costs,

$$
\text { Profits }=p q-T C=(a-b q) q-c-d q=(a-d) q-b q^{2}
$$

Choosing q so as to maximize profits yields the first-order condition where marginal revenue equals marginal cost:

$$
a-2 b q=d
$$

which can be solved for the profit-maximizing $q$, denoted $q^{*}$ :

$$
q^{*}=(a-d) / 2 b
$$

Substituting this $q^{*}$ into the inverse demand function (1) yields the profit-maximizing $p$, denoted $p^{*}$, as 


$$
p^{*}=(a+d) / 2
$$

This monopoly pricing solution is graphed in Figure 1.

Although some branded drugs are purchased by persons with no insurance or by those whose insurance does not cover the drug in question (e.g., some policies do not cover "lifestyle" drugs), the vast majority of drug purchases are made in connection with some insurance. In 2009 , only $21 \%$ of spending on prescription drugs in the US was out-of-pocket, and much of that represented cost sharing by insured consumers. ${ }^{8}$ Therefore we now consider pricing in the monopoly case with insurance.

Insurers set demand prices in one of two forms: as a coinsurance rate, in which the consumer pays a fixed percentage of the supply or procurement price, and as a copayment, in which the consumer pays a fixed dollar amount, say $\$ 25$, for a supply of the drug for a given period of time, usually a month. If the supply price is fixed, at say $\$ 100$, a $15 \%$ coinsurance is equivalent to a $\$ 15$ copayment. If this is all there were to the story, the choice between a coinsurance form and copayment form would be of no consequence. As we will show, however, the choice between coinsurance and copayment affects how the manufacturer sets supply price. The insurer and the enrollees will thus favor one over the other.

Begin with the coinsurance form. Denote the constant coinsurance rate as $i(0<i \leq 1){ }^{9}$ if the price of the drug is $p$, the patient pays ip. Coinsurance inflates the demand curve facing the seller. A patient willing to pay $\$ 20$ for a certain unit of the drug is still willing to pay $\$ 20$, implying the price the seller can charge is $\$ 20 / i$ and still sell the drug. The new inverse demand for the monopoly drug with coinsurance is, where $I^{-1}=1 / i$ :

$$
\mathrm{P}=\Gamma^{-1}(\mathrm{a}-\mathrm{bQ})=\mathrm{A}-\mathrm{BQ} \text {, where } \mathrm{A}=\Gamma^{-1} \mathrm{a} \text { and } \mathrm{B}=I^{-1} \mathrm{~b} \text {. }
$$


As seen in Figure 2, relative to the no insurance case, this with-insurance demand curve simply rotates clockwise and upward at the quantity demanded, rotating from the quantity where the price equals zero (compare with Figure 1), which from Eqns. (1) and (6) is where $q=a / b$ and $Q$ $=A / B=I^{-1} a / I^{-1} b=q .{ }^{10}$ The slope of the new inverse market demand curve becomes $B=I^{-1} b$. At any given price, demand is less elastic. At the new equilibrium with coinsurance (denoted with capital letters), from Eqn. (5) we see that

$$
\mathrm{P}^{*}=(\mathrm{A}+\mathrm{d}) / 2=\left(i^{-1} \mathrm{a}+\mathrm{d}\right) / 2
$$

and

$$
\mathrm{P}^{*} / \mathrm{p}^{*}=\left(i^{-1} \mathrm{a}+\mathrm{d}\right) /(\mathrm{a}+\mathrm{d})
$$

Since marginal cost $d>0$ and the coinsurance rate is $0<i \leq 1$, the profit-maximizing monopoly price with coinsurance will be greater than without insurance, i.e.,

$$
1<\mathrm{P}^{*} / \mathrm{p}^{*}<\mathrm{i}^{-1}
$$

The right hand side inequality rewritten states that the demand price falls with coinsurance ( $i \mathrm{P}^{*}$ $<\mathrm{p}^{*}$ ), implying that quantity demanded goes up with coinsurance. Thus, in general, both the supply price and the quantity demanded increase relative to the no insurance case, with the division between the two determined by the initial positions of the demand and marginal cost schedules. Note that if $i$ and $d$ are low, (8) implies that the increase in the supply price could be very large; as d goes to zero, the increase factor approaches $i^{-1}$. Figure 2 illustrates such a case. Consider now insurance in the form of requiring the patient to pay a fixed copayment (e.g., \$10 per month's supply) when purchasing the monopoly drug. The consequences of this would be catastrophic for the insurer and ultimately the consumer if the supplier could set price to maximize profits because the resulting drug price increases would translate into 
increased premiums. If the demand price is fixed, independent of supply price, the seller could set any price at all, and still sell the quantity demanded from (1) to an insured consumer. (We ignore the price elasticity of the demand for insurance; the resulting premium from very high drug prices may mean the insurer cannot break even.) In other words, from the point of view of the manufacturer of a drug, copayments put no constraint at all on monopoly prices.

Since coverage with coinsurance maintains a link between supply price and demand price, whereas coverage with copayments does not, coinsurance penalizes a monopolist with lost sales, at least to some degree, as the monopolist raises price.

Another form of coverage, not typically seen in the U.S. but observed often in other countries not only for the monopoly drug but also for the case of competing drugs, does even more to restrain manufacturers' price increases. Suppose the insurer declared that it would cover only $\$ x$ for each prescription purchased by the consumer, no matter what price the seller set, and that the consumer would need to pay the balance (the supply price minus the insurer's contribution) when purchasing the drug; this is called reference pricing, since the amount the insurer is willing to cover is often based on a comparison with prices of that drug in other countries or other drugs in the same class. ${ }^{11}$ As long as the insurer's payment is fixed at some amount, the monopolist will recognize that supply prices above that amount will simply move consumers along their demand curves, thereby reducing the quantity demanded. Note that with this strategy in the monopoly drug case, $\$ x$ are simply transferred to the monopolist, and there is no reduction in net price to the consumer. (The situation obviously differs with competing drugs.) 
It is informative to examine cost sharing provisions of insurers in the U.S. providing benefits to Medicare Part D beneficiaries. Insurers typically distinguish "specialty drugs" from more "everyday" drugs. Originally specialty drugs were injectable proteins derived through recombinant DNA technology. Today, however, specialty drugs include not only those drugs but also drugs that treat patients with chronic and complex diseases; they typically require special handling by pharmacists, providers, and patients. According to Medco, a large pharmacy benefit management (PBM) company,

"Traditionally, specialty drugs treated rare conditions affecting few patients. The special handling, administration, and patient monitoring requirements contribute to their cost, which can annually amount to tens of thousands of dollars for patients and tens of millions of dollars for plans. In the last decade, specialty drugs have become available to treat a broader range of illnesses." 12

For our purposes, it is appropriate to think of specialty drugs as being unique drugs having no close substitutes, i.e., as products marketed in pure monopoly markets.

In Figure 3 we reproduce median cost sharing provisions in stand-alone Medicare Part D prescription drug plans, weighted by enrollment, as published by MedPAC. (The time series begins in 2006 because that was the first year of the Part D drug insurance in Medicare.) As is seen in the bottom row of Figure 3, unlike the case for other drugs which have various copayments depending on tier (the reason for which we come to next), for specialty drugs there is a coinsurance rate, a rate that has in fact increased from $25 \%$ in 2006 to $33 \%$ in 2009 . Note that with a $33 \%$ coinsurance rate, relative to an uninsured market, the upper limit on price increases borne by the insurer (and ultimately by those who pay insurance premiums) is a factor of three. ${ }^{13}$ Effectively, coinsurance gives insurers some bargaining power over price, by shifting potentially greater exposure at the margin to beneficiaries than does a fixed 
copayment. Incidentally, in the specialty tier, unlike the other three tiers shown in Figure 3, Medicare does not allow beneficiaries to appeal for lower cost sharing; indeed, typically drugs on the specialty tier require prior authorization. ${ }^{14}$ In sum, the insight from economic theory that insurers choose coinsurance for unique monopoly products appears to apply to the market for specialty pharmaceuticals. ${ }^{15}$

\section{MARKETS WITH PATENT-PROTECTED SUBSTITUTE DRUGS: BERTRAND \\ COMPETITION}

A different and prevalent insurance contract arises when several drugs that are partial but not perfect substitutes compete with one another within a therapeutic class. An example of such competition would be the class of statin (cholesterol-lowering) drugs. Although some drugs in this class have now lost their patent protection and are generic, for several years there were a number of competing drugs, each of which had patent protection. More generally, even if some drugs in a class are generic, this example applies to competition between two or more drugs in the class when they are still on patent.

We cast this situation as a Bertrand model of differentiated products. ${ }^{16}$ Specifically, we consider two competing products that are on patent, first with no insurance, and then with copayments and formularies. ${ }^{17}$ The Bertrand model explains why an insurer may not offer both products, even though by excluding a product, some enrollees will not get their "best match" in terms of therapeutic option - or, more precisely, will have to pay an uninsured price to obtain it.

Suppose that firm 1 manufactures drug 1 and firm 2 manufactures drug 2. For convenience, let marginal production costs be zero. Let the demand functions from patients in 
the health plan for drugs 1 and 2 be $q_{1}\left(p_{1}, p_{2}\right)$ and $q_{2}\left(p_{1}, p_{2}\right)$, respectively. The goods are substitutes so cross-price terms are positive (e.g., $\left.\partial q_{1} / \partial p_{2}>0\right)$, and own-price effects are negative. Furthermore, we assume the products' demand functions are symmetric.

Consider pricing without insurance, assuming Bertrand competition between firms 1 and 2. Firm 1 maximizes profit, $\pi_{1}=p_{1} q_{1}\left(p_{1}, p_{2}\right)$ taking $p_{2}$ as given, and firm 2 maximizes $\pi_{2}=$ $p_{2} q_{2}\left(p_{1}, p_{2}\right)$ taking $p_{1}$ as given. We can describe the behaviors of the two firms in terms of "reaction functions", and graph them in Figure 4. $p_{1}\left(p_{2}\right)$ describes the best response or reaction function of $p_{1}$ to changes in $p_{2}$, and $p_{2}\left(p_{1}\right)$ is similarly the reaction function of $p_{2}$ to changes in $p_{1}$. Since the goods are substitutes in demand, $p_{1}{ }^{\prime}\left(p_{2}\right)>0$ and $p_{2}{ }^{\prime}\left(p_{1}\right)>0$. A firm would not want to raise its prices without limit, however, in response to a rival's behavior. Suppose the rival firm 2 set a very high price, sufficiently high that firm 1 is in effect a monopolist. In the limit $p_{1}(\infty)=p_{1}{ }^{m}$ where $p_{1}{ }^{m}$ is the monopoly price of firm 1 ; similarly for firm 2 . Since such a price maximizes a monopolist's profit, the firm would not want to increase its price further. We depict in Figure 4 both the monopoly price as well as the Bertrand (or Nash) equilibrium, $\left(p_{1}{ }^{b}, p_{2}{ }^{b}\right)$ where $p_{1}{ }^{b}=p_{1}\left(p_{2}{ }^{b}\right)$ and $p_{2}{ }^{b}=p_{2}\left(p_{1}{ }^{b}\right)$. Competition between the substitute products reduces price somewhat below the monopoly price, depending in part on how substitutable are the two drugs. ${ }^{18}$

Now introduce health insurance. If there were no connection between health insurance coverage decisions and procurement prices, the best thing for the insured group would be to have both products available in the plan; since they are differentiated, one product works better for some enrollees, the other product works better for others. 
Suppose, though, that the insurer implemented a formulary along with its coverage decision. The insurance takes the form of a reduction in the out-of-pocket price of a covered drug to $c$ (the copayment), but the insurer stipulates that only one of drugs 1 or 2 will be covered and available at copayment $c$. The other drug will not be covered so that any enrollee who wants to buy it must pay the full market price. Why might an insurer, in the interest of its enrollees, cover only one drug instead of two? To see the reason, consider how Bertrand price competition works in this case.

The game-theoretic formulation is as follows: In the first stage, the insurer announces that it will choose one drug and will offer that drug to its enrollees for copayment $c$. The drug chosen will be the one whose manufacturer offers the lower procurement price. The other drug will not be covered at all (will be "off-formulary"). Next, in the second stage, firms engage in Bertrand price competition by submitting binding bids simultaneously to the insurer. Finally, the insurer chooses a drug to be on the formulary.

Given the contract being offered by the insurer, being on the formulary offers the manufacturer an advantage. It will gain additional sales at the subsidized price of $c$ relative to the earlier uninsured price of $p^{b}$. Suppose we imagine firm 1 were to bid a price of $p_{1}^{b}$, the equilibrium in the original Bertrand competition. Firm 2, by reducing its price to just below $p_{1}^{b}$, would gain a large share of sales by taking business from firm 1 . Thus, $\mathrm{p}_{1}{ }^{\mathrm{b}}$ is no longer an equilibrium price, and each firm, anticipating this situation, will seek to undercut the other to obtain coverage by the insurer. Specifically, each firm will lower its price until the profit from 
the extra sales from being on the formulary is less than the profit a firm can make if its drug is off the formulary. Let the price that the winning firm bids at this point be $p^{f}$.

Assume firm 1 is the firm with the low bid, so consumers pay c for drug 1 . The new price that is optimal for firm 2 is the point on its reaction function $\mathrm{p}^{\mathrm{nf}}$ corresponding to a price of $c$ for drug 1. Figure 4 shows the new equilibrium prices for consumers with firm 1 winning as $\mathrm{p}\left(c, \mathrm{p}^{\mathrm{nf}}\right)$, where $c$ is the copay and $\mathrm{p}^{\mathrm{nf}}$ is firm $2^{\prime}$ s optimal price given that firm 1 has a supply price of $\mathrm{p}^{\mathrm{f}}$ and a demand price (patient copayment) of $c$.

Figure 4 shows that insured consumers face lower unit prices for both drugs than they did with no insurance. Moreover, focusing just on the effect of procurement prices, overall consumer welfare would have increased with drug insurance, since the premium or taxes necessary to finance the insurance plus the out-of-pocket spending to buy the old bundle of drugs is less than the amount consumers were spending without insurance. If this were not so, the formulary would have no economic value and consumers would not buy insurance of this type. A full accounting of the effect of insurance on economic welfare, however, would have to consider the loading charged by the insurer, the effect on risk, the effect on future drug development from lower revenues at drug manufacturers, spillover effects on non-drug health care utilization, and any static welfare gains assuming drug prices move closer to the marginal cost of production, which is low for most drugs. ${ }^{19}$

This framework also leads to two predictions and one observation. First, the closer the degree of substitution between the drugs, the lower the procurement price. The intuition can be seen by assuming the opposite case, that the drugs are hardly substitutable at all. Then the 
"losing" firm does not lose many sales by not being chosen - in the limit no sales at all - and therefore neither firm has much incentive to offer the insurer a low price and supply price remains near the uninsured price.

Second, the better is the coverage, i.e., the lower is $c$, other things equal, the lower is the procurement price. The intuition here is that the better the coverage, the more of the drug will be demanded and hence the greater the value of being the winning firm. Another way to see this is that in the limiting case as $c$ increases and approaches the uninsured price, the additional sales gained by the winning firm relative to the uninsured case go to zero.

Note that there will generally be some consumers who will respond best to a nonpreferred drug and for whom the on-formulary drugs are not good substitutes. Even this group, however, will pay less than in the no insurance case as long as there is some degree of substitutability between the two drugs.

In reality insurers use the more complex pricing arrangement shown in Figure 3, a tiered formulary with differential patient copayments to steer patients toward the insurer's preferred drugs. For example, within a given therapeutic class of medications that has a number of reasonably substitutable products (e.g., anti-cholesterol drugs), the insurer will typically put any generic drugs on the lowest tier, and offer the generic formulation to patients with a relatively low required copayment, e.g., \$10 for a 30-day prescription. Those branded products for which the insurer has negotiated a preferred lower price with one or more manufacturers are placed on a second tier; the insurer offers drugs on this second tier to patients with a higher required copayment, e.g., \$25 for a 30-day prescription. Those branded products within the same therapeutic class for which the insurer has been unable to negotiate a preferable price (perhaps 
the brand manufacturer refused to deviate from a no-discounted price policy) are then placed on a third tier; the insurer offers drugs on this third tier to patients with an even higher required copayment, e.g., $\$ 50$ for a 30 -day prescription. ${ }^{20}$

The Bertrand competition model explains why manufacturers are willing to offer discounts for more favorable tier placement. Although the modeling becomes more complicated, the logic of this Bertrand competition framework with just two drugs, one of which is on-formulary and one of which is off-formulary with no coverage, carries over to insurance benefit designs with two or more tiers, with the winning bidder having its product placed on the lowest copayment tier.

The copayment strategy is not optimal for the insurer in the monopoly drug case because, as pointed out above, coinsurance rather than copayment achieves the minimum price for consumers in the aggregate, taking account of both out-of-pocket payment as well as the premium or taxes necessary to finance insurance. The use of coinsurance, however, also has a downside: the consumer must bear the (often considerable) risk of out-of-pocket payments to use the drug. The optimal insurance contract will balance the dual aims of minimizing the procurement price of the drug and the amount of risk consumers bear. ${ }^{21}$ Anthony Barrueta, Senior Counsel for Kaiser Permanente, a large health maintenance organization, documents the relevance of our analyses in a real-world context. In joint hearings before the Department of Justice and the Federal Trade Commission, he noted that for unique drugs:

\footnotetext{
"Under these circumstances, there is little opportunity for a purchaser to stimulate competition among manufacturers. Manufacturers are roughly free to set launch prices, they rarely discount those prices, and purchasers are price takers." 22
} 
He contrasted this with the case of several patent-protected drugs competing with each other

in the same therapeutic area. He called this the "competing monopoly/oligopoly" stage, and described it as follows:

"This stage represents the lion's share of the market at any given time. Here, there are multiple similar drugs on the market, all still under market exclusivity protection. Depending on how similar the drugs are - that is, how substitutable they are for each other - organized purchasers have the ability to either switch patients in a medically appropriate manner among the drugs (if the drugs are highly substitutable) or at least start new patients on a preferred drug (if the drugs are similarly effective, but switching would be disruptive to therapy). In either case, there is a competitive opportunity that can be taken advantage of. This is the area where formularies can be applied for the greatest effect on overall costs." $^{23}$

When negotiating with a plan with a multiple-tier formulary, if the manufacturer insists on a high drug price it risks banishment to the third tier, where patients have the largest copayment, or not even being on the formulary, in which case the consumer pays the entire price out-of-pocket. Offering a low price to the plan buys favorable formulary placement, with the lower patient copayments increasing the quantity demanded of the drug. From the viewpoint of the insurer, the ability to obtain lower negotiated prices will depend on how credibly the insurer can "move market share" of drugs within the therapeutic class through physician education, tiered patient copayments, and other formulary management tools. ${ }^{24}$

Earlier we discussed reference pricing as a way of sharply restricting a monopolist's market power, with the insurer (rather than the insured) in effect making the fixed copayment, and the patient's demand price now being the varying balance between the supply price and the insurer's fixed contribution. In a number of countries, when there are several competing differentiated drugs within the same therapeutic class, the insurer will designate one particular 
drug (usually but not always a generic) as the "reference" drug, and will offer to pay no more than the supply price of that drug, regardless of which drug in that class is prescribed. With the consumer being responsible for the entire gap between the supply price and the insurer's fixed "copayment" (the varying demand price), reference pricing can become a powerful tool reducing manufacturers' market power in differentiated product markets. ${ }^{25}$

\section{MARKETS FOR GENERIC DRUGS: THE PERFECT COMPETITION PARADIGM}

Under provisions of the 1984 Waxman-Hatch legislation, prior to the patent expiration of the branded innovator product but only after the passage of five years since initially being approved for marketing by the U.S. Food and Drug Administration (FDA) (a time period designated "data exclusivity"), generic manufacturers can submit to the FDA a dossier called an Abbreviated New Drug Application ("ANDA"). In the ANDA they document, based on clinical studies, that their proposed drug formulation is bioequivalent to the patent protected innovator branded product, and that their manufacturing practices comply with certain regulations. Since the implementation of Waxman-Hatch, the generic applicant need not undertake and repeat costly clinical trials demonstrating safety and efficacy of the drug.

After reviewing the ANDA, the FDA can grant a tentative approval, with full approval becoming effective on the date of patent expiration or other market exclusivity provisions. ${ }^{26}$ In such cases, on the day the branded innovator's market exclusivity expires, generic manufacturers can market their approved product. Alternatively, generic manufacturers can choose to file their ANDA after market exclusivity expires, although that will delay their entry into the market. Since the clinical and administrative costs of establishing bioequivalence are relatively modest (estimated in the range of $\$ 2-5$ million ${ }^{27}$ ), and a well-known regulatory 
pathway exists, barriers to entry are minimal, and thus prices charged by generic manufacturers rapidly fall to marginal cost, consistent with competitive markets. ${ }^{28}$

The extent and impact of generic entry on average generic prices for the largest 25 new generics entering the U.S. market between 2005 and 2009 is illustrated in Figure $5 .^{29}$ The number of months since initial generic entry is plotted on the horizontal axis (up to a maximum of 40 months), the average generic price (indexed to 100 at time of initial generic launch) is on the left vertical axis, while the number of generic entrants is on the right vertical axis. Because not all generic molecules have been on the market for the full 40 months, for each month since launch the average is computed over the number of molecules having been on the market at least that length of time; thus, given the changing sample composition, the time trend since initial launch is not completely smooth.

As seen in Figure 5, the generic price index falls to a level of about 78 at month six, with an average number of generic entrants by that time of seven. By months 12 and 24 the average generic price index falls to about 50 and 23, respectively, and then stabilizes at about six after month 25, even as the average number of generic manufacturers gradually increases to about 10, 11 and 12, respectively.

Averaged over months 1-12 and 13-24 since initial generic entry, the 2005-2009 generic price indexes are 68 and 28, respectively. These price indexes are much lower than the comparable annual year one and year two price index values - 80 and 65 -- reported by Grabowski and Vernon [1992], based on 1984-1991 major generic launches. We infer that generic entry and price competition following loss of market exclusivity has intensified over the last quarter century since the 1984 passage of the Waxman-Hatch legislation. 
This depiction of generic competition following loss of market exclusivity holds in most cases, with three notable exceptions. Under Waxman-Hatch, the first generic manufacturer that successfully prevails in challenging the brand innovator's patent claims can be granted 180 days of exclusivity during which time no other ANDA holder for that molecule/strength can market its product. This is called a Paragraph IV entry.

With no further ANDA entry permitted for a period of 180 days, the market for that particular molecule/strength becomes a duopoly, with the branded manufacturer and the single generic manufacturer being the two competitors. During this time period, the price of generics is generally only $10-20 \%$ less than that of the brand, considerably above marginal cost.

A variant of this occurs when the branded manufacturer enters into an agreement with a generic manufacturer other than the successful Paragraph IV entrant to market the molecule/strength under the branded product's original New Drug Application (rather than an ANDA) during the 180 day exclusivity period. This is called "authorized generic entry", and it enables the innovator branded company to continue pricing its product in a now triopoly market for up to 180 days, rather than ceding all generic sales to the single successful Paragraph IV entrant. ${ }^{30}$ Following expiration of the 180 day Paragraph IV exclusivity period, generic entry tends to be rapid and substantial, with generic prices falling sharply. This is seen in Figure 5, where a particularly large price drop occurs during month seven.

A second exception involves what are called "branded generics" - branded products from manufacturers other than the original innovator patent holder entering with a similar strength (or with an off-patent molecule in combination with other molecules) therapeutic formulation but branded with other than the generic name. Branded generics seek to 
differentiate themselves from both the original patent holder and other generic entrants, relying on their historic reputation for high quality manufacturing, and generally attempt to charge prices in between the generic and original brand. ${ }^{31}$ Branded generics were more common in the 1970s and 1980s; over the last few decades they have tended not to be particularly successful, but as we discuss next, in the future they may be rejuvenated in the context of biosimilars.

A third potential exception to generic markets being characterized as competitive with prices close to marginal cost involves biologics. Unlike small molecule, chemically synthesized pharmaceuticals that can readily be described analytically, larger molecule, often protein-based biologics are complex, and because of their larger size, their surfaces can fold in different ways, thereby not blocking receptor sites as uniformly as synthesized small molecules. ${ }^{32}$

Derived from living organisms, biologics can change in unpredictable ways, and are therefore more challenging and costly to manufacture. Importantly, characterizing them analytically and establishing bioequivalence between the original biologic and an attempted follow-on biologic entrant raises difficult scientific issues and regulatory challenges. Notably, section 7001 of the 2010 health care reform legislation (the Patient Protection and Affordable Care Act) established the authority for the FDA to license biosimilars and provided the original biologic twelve years of data exclusivity (seven more than for small molecules). Because of the greater manufacturing cost, complexity and regulatory uncertainty, however, it is widely anticipated that the extent and speed of follow-on biologic entry subsequent to loss of patent protection will be considerably less than has historically been observed with chemically 
synthesized small molecules. Hence the branded generic or biosimilar price declines will likely be correspondingly less rapid and steep, with prices remaining above marginal costs. ${ }^{33}$

Although an upstream generic drug manufacturer eventually faces an approximately competitive market, perfect competition may not prevail in the downstream markets. Distribution of generic drugs has been found to be especially profitable for both pharmacy benefit managers (drug insurers) and retail outlets. ${ }^{34}$ One candidate explanation is market power of pharmacy benefit managers (PBMs) and retailers. In fact, the PBM industry is reasonably concentrated in three large firms, Express Scripts, Medco, and Caremark/CVs ${ }^{35}$, and the retail industry is also somewhat concentrated in large chains. In 2010 Caremark/CVS, Walgreens, and RiteAid had an estimated 20, 16 and 6 percent of retail and mail order sales in the US market respectively; WalMart has another 6 percent. $^{36}$

These data, however, likely understate the market power that the large chains have in the retail market for several reasons. First, the denominator for the market share data just quoted includes mail order prescriptions from Medco and Express Scripts, two firms that do not have retail pharmacies but have 15 percent of the total market between them. The data also include some "specialty" pharmaceuticals, and those drugs are typically not sold at retail. Second, these are national data, but retail pharmacy is a quintessential local market. Third, and perhaps most importantly, both public and private purchasers contracting for drug insurance will typically require that a given percentage of beneficiaries be within a certain distance of an in-network pharmacy (e.g., $90 \%$ of those insured are within five miles of an in-network pharmacy). This condition gives the large chains an ability to extract discounts from drug 
insurers whose market is typically at least a state if not nationwide. (Some health insurers are also drug insurers; others "carve out" or subcontract drug insurance to a large PBM. Some employers will also contract the drug insurance for their employees to a PBM.) To the degree the PBMs are earning greater rents on generic drugs because of the competitive condition of the downstream product market described above, this market power becomes a way for the retail chains to extract some of those rents. This market power may be starting to break down, however, as we describe below.

\section{INSIGHTS GAINED FROM THESE MODELS}

Familiar tools taken from basic microeconomic theory textbooks can unravel some of the elements of "confusopoly" pricing in pharmaceutical markets. It is useful to elaborate on some of the insights we have gained from these models.

\section{A. COPAYMENTS FOR SELECTED COMPETING DIFFERENTIATED PRODUCTS}

When a number of patent-protected drugs within the same therapeutic class are reasonably substitutable, the insurer can stimulate price competition among manufacturers by offering a formulary, covering some, but not all drugs, with tiered copayments. As seen in Figure 3, for the most part this is what Medicare Part D Prescription Drug Plans do; in 2009 the median copayment for tier 1 generic drugs was $\$ 7$ for a month's supply, for tier 2 preferred brand-name drugs it was $\$ 38$, and for tier 3 non-preferred brand-name drugs, it was $\$ 75$. Typically, a subset of drugs are on the preferred brand tier. The insurer increases its bargaining power by limiting the number of preferred brands, and by lowering the copayment for the preferred tier. Each of these contribute to its power to "move market share" to the preferred drug. The US Veterans' Administration, for example, puts this strategy to work: in the anti- 
cholesterol and acid-preventing proton pump inhibitor therapeutic classes, only one drug is on the formulary in each class, and no other drugs are covered. ${ }^{37}$ Moreover, as documented in Duggan and Scott-Morton [2010] based on 2003-2006 data, brands with few therapeutic substitutes and high sales to Part D eligibles did not experience the price decline relative to trend evidenced by drugs with several substitutes, trends consistent with the plans' formularies stimulating competition and lowering prices.

While in theory insurers could employ dollar-equivalent differential coinsurance rates in differentiated drug product markets, fixed copayment levels have the advantage of administrative simplicity and transparency, as well as enabling consumers to budget confidently for near term pharmaceutical costs. Furthermore, utilizing coinsurance rather than copayments could facilitate disclosure of information about the insurer's procurement prices, information that the insurer and/or the manufacturer may be reluctant to make public.

\section{B. HOW MANY THERAPEUTIC CLASSES TO DISTINGUISH ON FORMULARY?}

On average about twenty new drugs are approved annually by the FDA. Since 1960 about 1000 new drugs have received FDA approval; one estimate is that from 1945 to 2005, about 1200 new drugs have been approved by the FDA. ${ }^{38}$ The greater the number of distinct therapeutic classes that a formulary distinguishes, the smaller the number of distinct competitor molecules within each class; alternatively, the smaller the number of therapeutic classes, the greater the number of competitors within each class. The specification of the boundaries of distinct therapeutic classes affects the number of manufacturers that compete with each other within a class, and therefore has implications for the extent of price competition among manufacturers. In 2009 Medicare Part D designated 146 distinct 
therapeutic classes, which were (and are) determined by the United States Pharmacopeia rather than the insurers offering Part $D$ insurance plans; all insurers offering Part $D$ plans must use these 146 classes. ${ }^{39}$ In the commercial (under 65 years of age) insurance market there is considerable heterogeneity among the number of classes that various insurers use, with some having more and others fewer than Medicare Part D.

Moreover, Medicare requires insurers offering Part D plans to have at least two covered products in 140 therapeutic classes, but it designates six protected classes in which drugs are thought not to be close substitutes and therefore requires that insurers offer coverage for all but one of the drugs in each of these six classes. ${ }^{40}$ Even if a class has a large number of drugs, any given patient may only do well on one or a few of them. Examples of two such classes, which are two of the six that are protected by Medicare, are antidepressants and antipsychotics. In such cases, from the vantage of patients that respond idiosyncratically, the drugs are not very substitutable. Medicare's requirement that all but one drug in the class be on the formulary, however, gives manufacturers of patent-protected drugs in these classes additional market power, enabling them to price substantially above marginal cost, without having to worry as much about potential Bertrand differentiated products price competition. ${ }^{41}$

\section{NEW PRICE COMPETITION AT THE RETAIL LEVEL}

In recent years giant retailer WalMart has taken several actions that mimic the formulary model in the context of retail drug distribution and competition rather than drug manufacture. For a large number of generic drugs, WalMart announced in 2008 it would charge $\$ 4$ for a 30 -day prescription and $\$ 9$ for a 90 -day prescription, whereas at that time insured consumers going to chains such as CVS, RiteAid, and Walgreens typically had a larger 
copay (as seen in Figure 3, the median generic copay for a 30-day prescription in a Part D plans in 2009 was \$7). ${ }^{42}$ Later in 2008 WalMart aligned with insurers such as Humana and employers such as Caterpillar to offer consumers a zero drug copayment for generics at WalMart, whereas consumers would pay a normal $\$ 5$ copayment if they filled their prescriptions at non-WalMart pharmacies. The resulting increased volume at WalMart not only gave it more bargaining power vis-à-vis generic manufacturers, but it also brought foot traffic into its stores to purchase non-drug products.

Competitor drug retail chain Walgreens reacted, offering 90-day prescriptions for $\$ 12.99$, equivalent to 30 -day prescriptions for $\$ 4.33$ (plus an annual membership fee). ${ }^{43}$ Finally, in late 2008 the combined pharmacy benefit management firm Caremark and retail chain CVS announced a new Health Savings Plan that let customers buy 90-day supplies of over 400 generic drugs for $\$ 9.99$ (plus a $\$ 10$ annual membership fee) either through its mail order or at its retail sites, calling this "channel neutrality", and noting that it hoped that by shifting its 90day mail order prescriptions to be picked up at its retail stores, it would bring customers into the store. These developments document that Bertrand price competition is alive and growing in the retail prescription drug store market segment as well as in the upstream manufacturing market for competing branded products. ${ }^{44}$

\section{FINAL REMARKS}

At the outset of this primer we noted that because of the importance of asymmetric information, principal-agent issues involving physicians, payers and patients, along with moral hazard and adverse selection in health care markets, in general one cannot rely on simple demand theory to make normative statements and evaluations of how well health care markets 
are performing. Put simply, in health care we cannot credibly assume that representative consumers are rationally maximizing utility subject to budget constraints.

While our inability to rely on conventional consumer demand theory limits our ability to make unambiguous welfare statements about how well health care markets are working, we do know that market demand functions exist, whatever their sources. Using those functions along with the familiar frameworks of competition, monopoly and Bertrand differentiated product price competition, we can still productively employ microeconomic tools, as well as theories of firms and markets, to help us better understand the "confusopoly" of pricing in biopharmaceutical markets. 


\section{REFERENCES}

Abelson, Reed and Natasha Singer [2011], "Pharmacists Fight the Rise of Mail Order", New York Times, March 3. Available online at http://www.nytimes.com/2011/03/04/business/04drug.html?emc=etal\&pagewanted= print, accessed March 4, 2011.

Adams, Scott [1997], The Dilbert Future, New York: HarperCollins.

Barrueta, Anthony [2003], "Pharmacy Benefit Management Companies (PBMs)", comments of Senior Counsel, Kaiser Foundation Health Plan, Inc., Oakland, California, before the Federal Trade Commission/Department Of Justice Joint Hearings, Health Care and Competition Law and Policy, June 26, 2003, p. 1; accessed online at www.ftc.gov/ogc/healthcarehearings/docs/030626barrueta.pdf.

Berndt, Ernst R. [2002], "Pharmaceuticals in U.S. Health Care: Determinants of Quantity and Price", Journal of Economic Perspectives 16(4):45-66, Fall.

Berndt, Ernst R. and Murray L. Aitken [2010, 2011], “Brand Loyalty, Generic Entry and Price Competition in Pharmaceuticals in the Quarter Century After the 1984 Waxman-Hatch Legislation." Cambridge MA: National Bureau of Economic Research, Working Paper 16431, October 2010. Forthcoming, International Journal of the Economics of Business, June 2011.

Berndt, Ernst R. and Richard G. Frank [2007], "Medicare Part D and Prescription Drug Prices", Survey of Current Business 87(6):59-71, June.

Berndt, Ernst R., Richard Mortimer, Ashoke Bhattacharjya, Andrew Parece and Edward Tuttle [2007], "Authorized Generic Drugs, Price Competition and Consumers' Welfare", Health Affairs 26(3):790-9, May/June.

Berndt, Ernst R. and Joseph P. Newhouse [2010, 2011], Pricing and Reimbursement in U.S. Pharmaceutical Markets", Cambridge MA: National Bureau of Economic Research, Working Paper No. 16297, August. Revised version forthcoming in Patricia M. Danzon and Sean N. Nicholson, eds., The Economics of the Biopharmaceutical Industry, Oxford: Oxford University Press, 2011.

Cook, Anna [1998], How Increased Competition from Generic Drugs Has Affected Prices and Returns in the Pharmaceutical Industry, Washington DC: The Congress of the United States, Congressional Budget Office. Available online at http://www.cbo.gov/. 
Drug Channels [2007a], "Wal-Mart adds some \$4 generics (yawn)", September 27. Available at http://www.drugchanels.net/2007/09/wal-mart-adds-some4-generics-yawn.html.

Drug Channels [2007b], "Wal-Mart's Gain is not Walgreen's Pain", October 2. Available at http://www.drugchannels.net/2007/10/wal-marts-gain-is-not-walgrens-pain.html.

Drug Channels [2008a], "Wal-Mart Redux", May 7. Available at

http://www.drugchannels.net/2008/05/wal-mart-redux.html.

Drug Channels [2008b], "Walgreens' \$4.33 Surrender to Wal-Mart", June 25. Available at http://www.drugchannels.net/2008/06/walgreens-433-surrender-to-wal-mart.html.

Drug Channels [2008c], "WMT + CAT: Pharmacy's Future?", September 25. Available at http://www.drugchannels.net/2008/09/wmt-cat-pharmacys-future.html.

Drug Channels [2008d], "New Details on WMT-CAT Pharmacy Deal", November 6. Available at http://www.drugchannels.net/2008/11/new-details-on-wmt-cat-pharmacy-deal.html.

Duggan, Mark, Patrick Healy and Fiona Scott Morton [2008], "Providing Prescription Drug Coverage to the Elderly: America's Experiment with Medicare Part D", Journal of Economic Perspectives 22(4):69-92, Fall.

Duggan, Mark and Fiona Scott Morton [2010], "The Effect of Medicare Part D on Pharmaceutical Prices and Utilization", American Economic Review 100(1):590-607, March.

Ellis, Randall P. and Willard G. Manning [2007], "Optimal Health Insurance for Prevention and Treatment," Journal of Health Economics 26(6):1128-50.

Federal Trade Commission [2009], Emerging Health Care Issues: Follow-on Biologic Drug Competition, June. Available online at www.ftc.gov/opa/2009/06/biologics.shtru.

Federal Trade Commission [2009a], Authorized Generics: An Interim Report of the Federal Trade Commission, June. Available at http://www.ftc.gov/opa/2009/06/generics.shtm, last accessed 14 July 2010.

Federal Trade Commission [2009b], Emerging Health Care Issues: Follow-on Biologic Drug Competition, June. Available online at www.ftc.gov/opa/2009/06/biologics.shtru.

Frank, Richard G. [2001], "Prescription Drug Prices: Why Some Pay More Than Others Do", Health Affairs 20(2):115-28, March/April. 
Frank, Richard G. and Joseph P. Newhouse [2007], "Mending the Medicare Prescription Drug Benefit: Improving Consumer Choices and Restructuring Purchasing", Washington DC: The Brookings Institution, Hamilton Project Discussion Paper 2007-03, April.

Frank, Richard G. and Joseph P. Newhouse [2008], "Should Drug Prices Be Negotiated Under Part D of Medicare? And If So, How?", Health Affairs 27(1):33-43, January/February.

Frank, Richard G. and David S. Salkever [1992], "Pricing, Patent Loss and the Market for Pharmaceuticals", Southern Economic Journal 59(2):165-179, October.

Frank, Richard G. and David S. Salkever [1997], "Generic Entry and the Pricing of Pharmaceuticals", Journal of Economics and Management Strategy 6(1):75-90, Spring.

Frueh, Felix W., Shashi Amur, Padmaja Mummaneni, Robert S. Epstein, Ronald E. Aubert, Teresa M. DeLuca, Robert R. Verbrugge, Gilbert J. Burckart and Lawrence J. Lesko [2008], "Pharmacogenomic Biomarker Information in Drug Labels Approved by the United States Food and Drug Administration: Prevalence of Related Drug Use", Pharmacotherapy 28(8):992-998, August.

Gaynor, Martin, Deborah Haas-Wilson, and William B. Vogt [2000], “Are Invisible Hands Good Hands? Moral Hazard, Competition, and the Second-Best in Health Care Markets", Journal of Political Economy 108(5):992-1005, October.

Glazer, Jacob, Haiden A. Huskamp and Thomas G. McGuire [2011], “A Prescription for Drug Formulary Evaluation", Boston, MA: Harvard Medical School, Department of Health Care Policy, unpublished, February 25.

Goldman, Dana P., Geoffrey F. Joyce, Grant Lawless, William H. Crown and Vincent Willey [2006], "Benefit Design and Specialty Drug Use", Health Affairs 25(5):1319-31, September/October.

Grabowski, Henry G. [2008], "Follow-on Biologics: Data Exclusivity and the Balance Between Innovation and Competition", Nature Reviews: Drug Discovery 7:479-88, June, doi:10.1038/nrd2532.

Grabowski, Henry G., lain M. Cockburn and Genia Long [2006], "The Market for Follow-On Biologics: How Will It Evolve?", Health Affairs 25(5):1.

Grabowski, Henry G. and John M. Vernon [1992], "Brand Loyalty, Entry, and Price Competition in Pharmaceuticals after the 1984 Drug Act", Journal of Law and Economics 35:331-340, October. 
Grabowski, Henry G. and John M. Vernon [1996], "Longer Patents for Increased Generic Competition in the US: The Waxman-Hatch Act after One Decade", Pharmacoeconomics 10 Suppl2:110-123.

Kanavos, Panos and Uwe Reinhardt [2003], "Reference Pricing in the United States?", Health Affairs 22(3):16-30, May/June.

Lakdawalla, D and Sood, N. [2009] "Innovation and the Welfare Effects of Public Drug Insurance," Journal of Public Economics 93:541-48.

Mas-Colell, Andreu, Michael D. Whinston, and Jerry R. Green [1995], Microeconomic Theory, New York: Oxford University Press.

Medco [2011], 2010 Drug Trend Report. Available online at www.medco.com; also available at www.drugtrend.com.

Pauly, Mark V. [2010], "Insurance and Drug Spending", Philadelphia, PA: University of Pennsylvania, The Wharton School, unpublished manuscript, December 10. Forthcoming in Patricia M. Danzon and Sean N. Nicholson, eds., The Economics of the Biopharmaceutical Industry, Oxford, UK: Oxford University Press, 2011.

Pindyck, Robert S. and Daniel L. Rubinfeld [2009], Microeconomics, $7^{\text {th }}$ Edition, Upper Saddle River, New Jersey: Pearson Prentice-Hall.

Pollack, Andrew [2011], "Coupons for Patients, but Higher Bills for Insurers", New York Times, January 2. Available online at http://www.nytimes.com/2011/01/02/business/02coupon.html? $r=1 \&$ pagewanted=print, last accessed 10 March 2011.

Reiffen, David E. and Michael E. Ward [2005], "Generic Drug Industry Dynamics", Review of Economics and Statistics 87(1):37-49.

Reiffen, David E. and Michael E. Ward [2007], "'Branded Generics' As A Strategy to Limit Cannibalization of Pharmaceutical Markets", Managerial and Decision Economics_28:251-65.

Saha, Atanu, Henry G. Grabowski, Howard M. Birnbaum, Paul E. Greenberg and Oded Bizan [2006], "Generic Competition in the U.S. Pharmaceutical Industry", International Journal of the Economics of Business 13(1):15-38, February.

Trusheim, Mark R., Murray L. Aitken and Ernst R. Berndt [2010], “Characterizing Markets for Biopharmaceutical Innovations: Do Biologics Differ From Small Molecules?", Forum for Health Economics \& Policy, Manuscript 1200, June, 48pp. Available online at http://www.bepress.com/fhep. 
Wal-Mart [2010], “\$4 Prescriptions Program", available online at http://www.walmart.com/p/4-Prescriptions-Program/546834, last accessed March 21, 2010. 


\section{FIGURE 1}

\section{Monopoly Pricing with No Coinsurance}

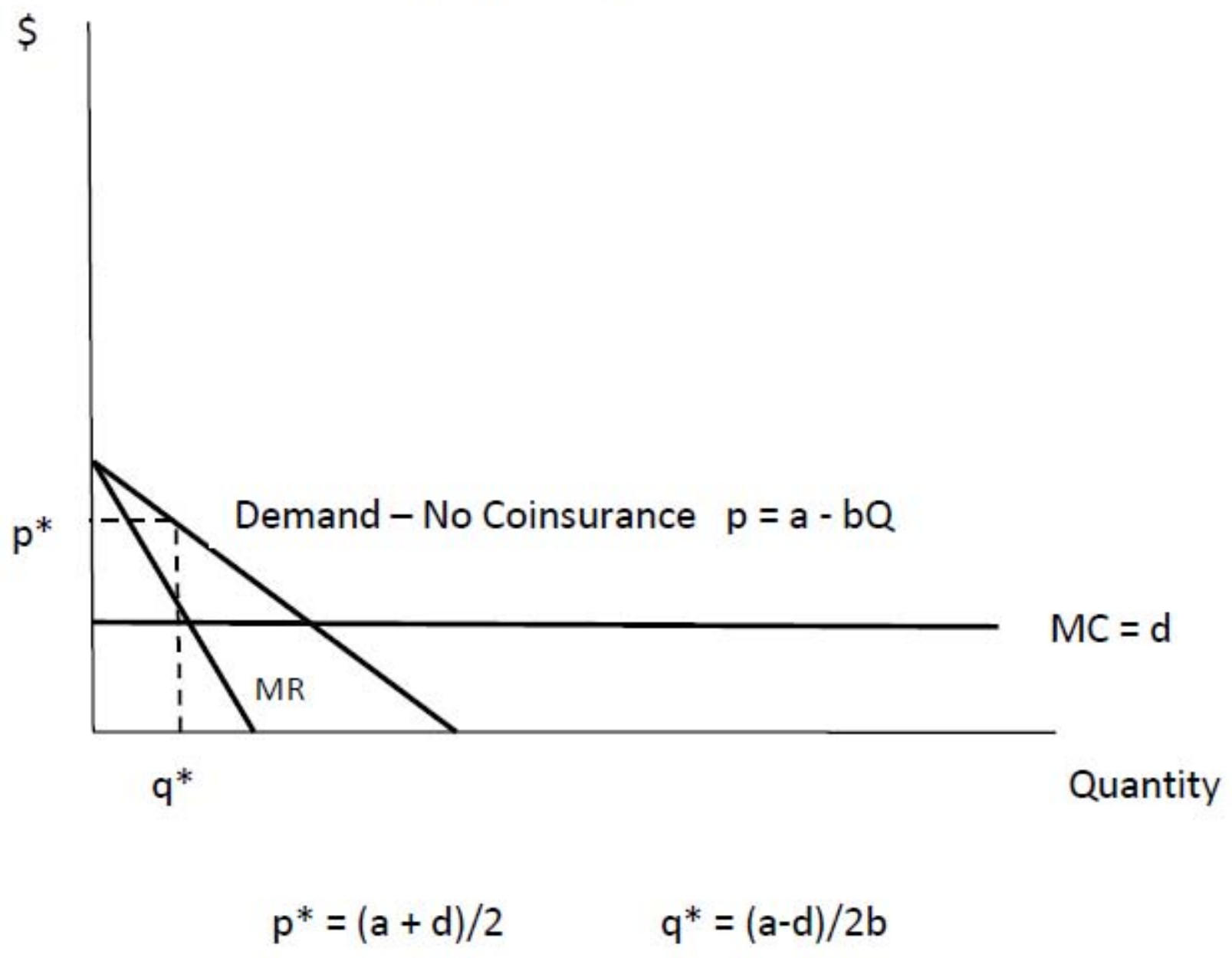




\section{FIGURE 2}

Monopoly Pricing with Coinsurance: One Case

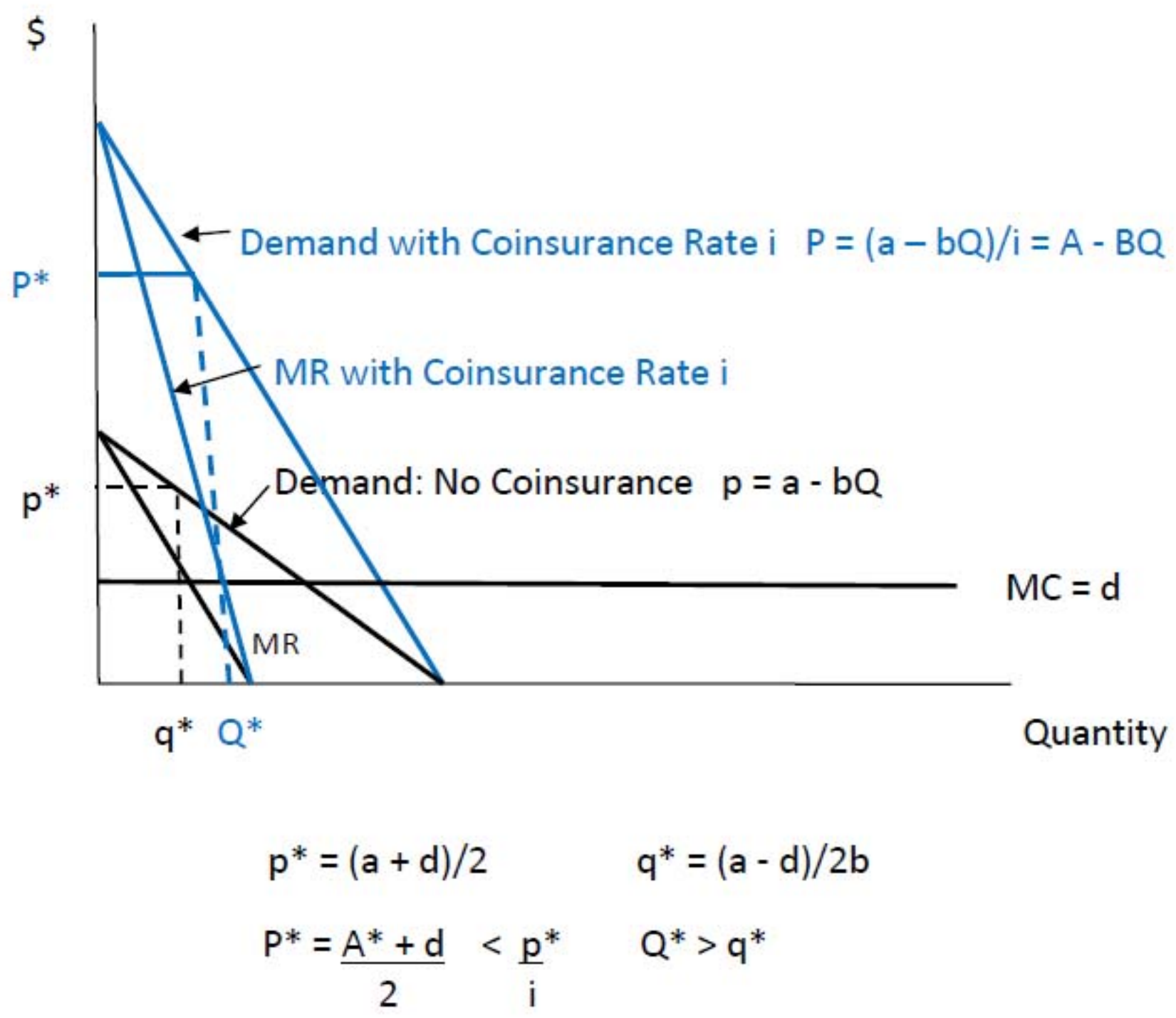




\section{FIGURE 3}

\section{Cost Sharing in the Median Medicare Part D Plan}

\begin{tabular}{|l|c|c|c|c|}
\hline & \multicolumn{3}{|c|}{ Stand-Alone Prescription Drug Plans } \\
\hline & 2006 & 2007 & 2008 & 2009 \\
\hline Copay for a month's supply & & & & \\
\hline Generic & $\$ 5$ & $\$ 5$ & $\$ 5$ & $\$ 7$ \\
\hline Preferred brand-name drug & 28 & 28 & 30 & 38 \\
\hline Non-preferred brand name drug & 55 & 60 & 72 & 75 \\
\hline Specialty tier coinsurance rate & $\mathbf{2 5 \%}$ & $\mathbf{3 0 \%}$ & $\mathbf{3 0 \%}$ & $\mathbf{3 3 \%}$ \\
\hline
\end{tabular}

Source: Medicare Payment Advisory Commission, March 2009, Table 4-8. Values weighted by enrollment. Values for Medicare Advantage Prescription Drug plans are similar. 


\section{FIGURE 4}

\section{Bertrand Price Competition}

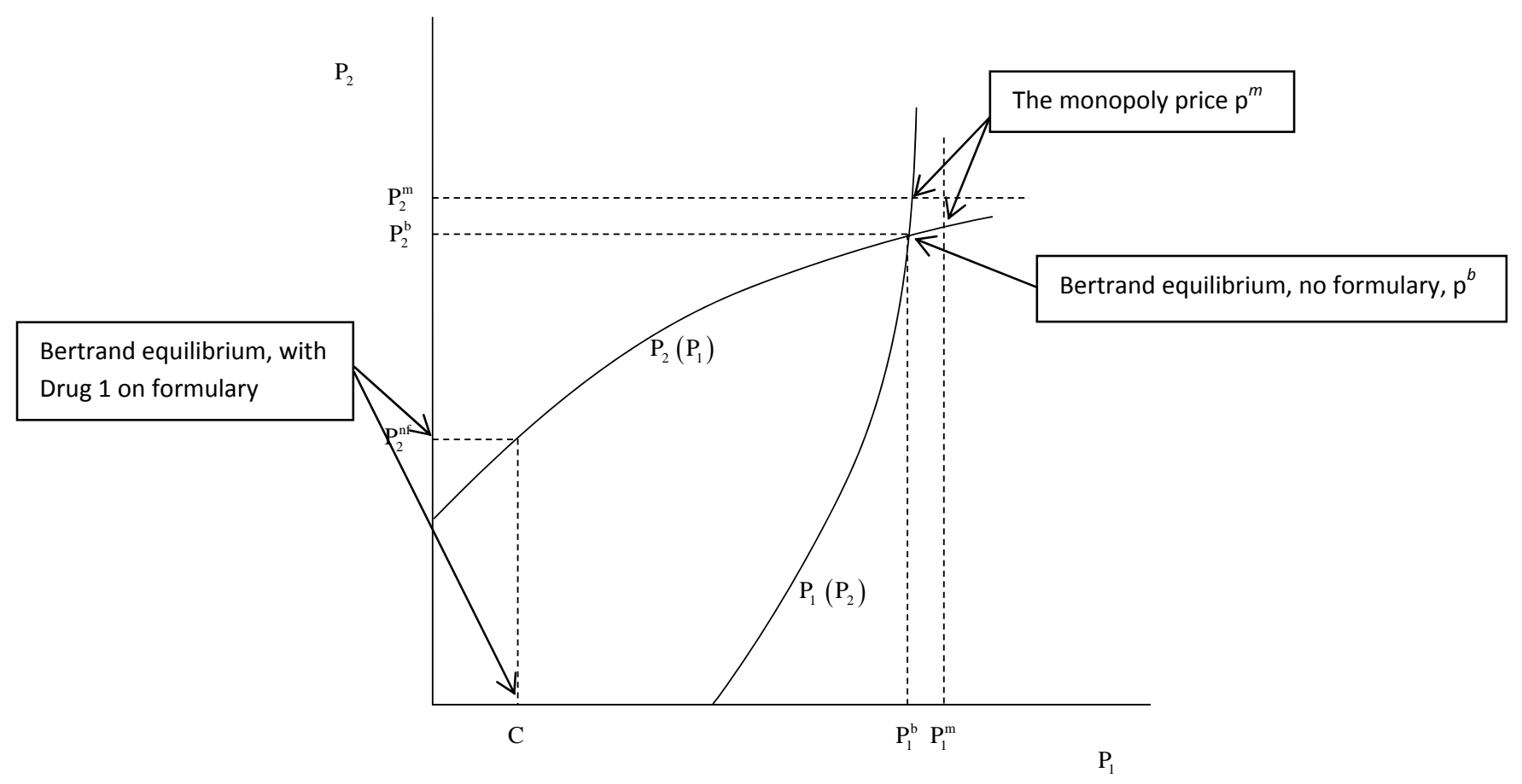




\section{FIGURE 5}

Average Generic Price and Number of Generic Manufacturers Following Initial Generic Entry, Top 25 New Generics 2005-2009

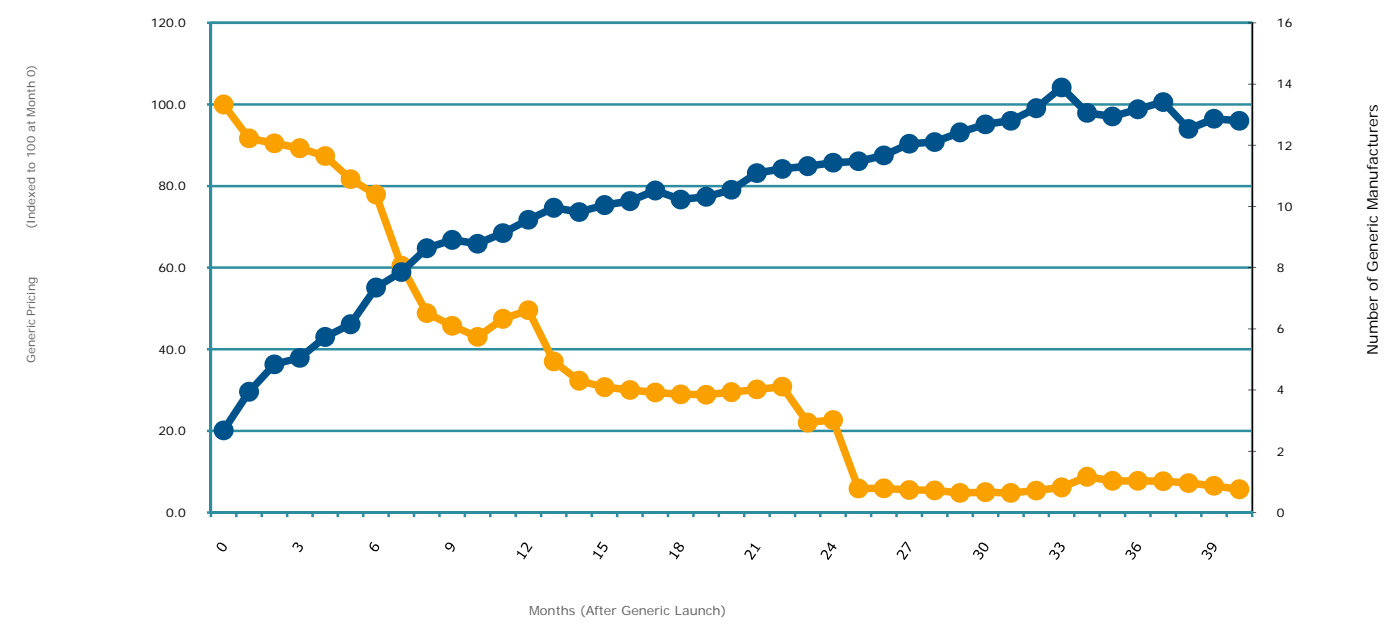

Source: Berndt and Aitken [2010], Figure 3. 


\section{ENDNOTES}

${ }^{1}$ Available online at http://www.dilbert.com/strips/comic/2010-11-21/, last accessed February 7, 2011. It is worth noting that in his 1997 book The Dilbert Future (Harper Collins, June 1, 1997, ISBN 0-75221161-7) Scott Adams first defined confusopoly as "A group of companies with similar products, who intentionally confuse customers instead of competing on price." (p. 159). Examples of industries in which confusopolies exist (according to Adams) include telephone service, insurance, mortgage loans, banking, financial services and retail electricity markets (but not health care or pharmaceuticals). For further discussion and references (including an economic analysis of pricing in deregulated energy markets in Australia by Joshua Gans), see http://en.wikipedia.org/wiki/The Dilbert Future, last accessed March 10, 2011.

${ }^{2}$ This primer builds on our previous writings, in particular on Berndt and Newhouse [2010,2011], Berndt and Aitken [2010,2011], Berndt and Frank [2007], Frank and Newhouse [2007,2008], Frank [2001] and Berndt [2002].

${ }^{3}$ In a formal analysis, Gaynor, Haas-Wilson and Vogt [2000] show that a lower procurement price is in the interest of the insurer pressured by competition to maximize utility of enrollees, and in the interest of social welfare. In other words, higher procurement prices are not a useful antidote to "overconsumption" caused by moral hazard in insurance coverage.

${ }^{4}$ Lakdawalla and Sood (2009) point out that the presence of an insurer allows for supply prices for new drugs to be maintained at high levels exceeding marginal production cost to encourage innovation, but demand prices to be set low to encourage efficient consumption. Social and private benefits and costs of drug insurance are also considered in Glazer, Huskamp and McGuire [2011].

${ }^{5}$ Even if there were a monopoly drug insurer in the U.S., drug research and development decisions are taken with the world market in mind, and the U.S. is typically slightly less than half that market.

${ }^{6}$ Clearly if the markets for two different molecules are of markedly different size, however, marketing costs will vary. Because marginal production cost is typically "low," the marginal revenue from selling another tablet or capsule is nearly all profit. Hence, incentives to invest heavily in marketing are substantial, something for which pharmaceutical manufacturers are notorious. Note that marketing costs are in the nature of a capital good, since the manufacturer is investing in the future returns of establishing a brand name. American accounting conventions treat such costs as a current period expense, which inflates accounting profits on assets relative to economic profits. See Berndt [2002] for further discussion and references.

${ }^{7}$ The demand from those without insurance can simply be incorporated into the market demand curve. ${ }^{8}$ See http://www.cms.gov/NationalHealthExpendData/02_NationalHealthAccountsHistorical.asp\#TopOfPage.

${ }^{9}$ The case of full coverage with coinsurance or copayment (zero contribution by the insured) puts no restraint on monopoly pricing, and we disregard this polar case.

${ }^{10}$ Note that the implicit assumption here is that consumers' saturation when the drug is free (price of zero) is unchanged with and without coinsurance, so that the intersection of the demand curve with the horizontal axis is unaffected. While intuitively plausible, one could envisage situations where an insurer provided insurees information concerning benefits of taking drugs that an uninsured consumer did not receive (e.g., in an effort to increase compliance with taking prescribed medications and lower hospital and physician spending), so that under insurance it is possible that at a zero price the quantity utilized would be greater than under the no insurance scenario.

${ }^{11}$ Kanavos and Reinhardt [2003].

${ }^{12}$ Medco [2011], p. 23. 
${ }^{13}$ The factor of three applies with zero marginal production costs, but unlike other drugs, production costs for specialty drugs are typically non-trivial, diminishing the factor by which coinsurance raises the profit-maximizing price.

${ }^{14}$ For further discussion of the treatment of specialty drugs in the Medicare Part D program, see Duggan, Healy and Scott Morton [2008].

${ }^{15}$ For further discussion of specialty drugs and drug insurance benefit design, see Goldman, Joyce, Lawless et al. [2006]. Issues regarding factors affecting optimal coinsurance rates for prevention and for treatment are considered by Ellis and Manning [2007].

${ }^{16}$ Textbook treatments of Bertrand competition are found in, for example, Mas-Colell, Whinston and Green [1995, ch. 12] and Pindyck and Rubinfeld [2009, ch. 12].

${ }^{17}$ As we show, copayments, combined with the ability to choose suppliers as part of a formulary, give an insurer the ability to influence procurement prices. Analysis of the alternative of coinsurance adds no further insights.

${ }^{18}$ Duggan, Healy and Scott Morton [2008].

${ }^{19}$ Glazer, Huskamp and McGuire [2011] discuss welfare implications of prescription drug insurance in greater detail.

${ }^{20}$ Recently some manufacturers of products placed on the third copayment or coinsurance tier have attempted to counter the insurer's formulary placement of their product by providing consumers with coupons that reduce and perhaps even eliminate the patient's differential copayments between tiers; see, for example, Pollack [2011].

${ }^{21}$ For further discussion of economic issues underlying optimal insurance in the context of prescription drugs, see Pauly [2010] and Glazer, Huskamp and McGuire [2011].

${ }^{22}$ Barrueta [2003].

${ }^{23}$ Ibid.

${ }^{24}$ Berndt [2002], Frank and Newhouse [2007,2008], Duggan, Healy and Scott Morton [2008] and Duggan and Scott Morton [2010].

${ }^{25}$ An interesting research question would be to compare the properties of the European-based approach, reference pricing, to the US-based approach, formularies and tiering.

${ }^{26}$ These other market exclusivity provisions include, for example, six months of additional market exclusivity beyond patent expiration for undertaking certain clinical investigations involving pediatric populations.

${ }^{27}$ See, for example, Reiffen and Ward [2005] and Saha, Grabowski, Birnbaum, Greenberg and Bizan [2006].

${ }^{28}$ We do not discuss the innovator's optimal pricing strategy following loss of patent protection and generic entry. This situation has been considered by, among others, Frank and Salkever [1992, 1996], Cook [1998] and Berndt [2002].

${ }^{29}$ Taken from Berndt and Aitken [2011], Figure 3.

${ }^{30}$ For further discussion of authorized generic entry issues, see Berndt, Mortimer, Bhattacharjya, Parece and Tuttle [2007], and Federal Trade Commission [2009a].

${ }^{31}$ Reiffen and Ward [2007].

${ }^{32}$ For a comparison of small molecules and biologics post-launch, see Trusheim, Aitken and Berndt [2010].

${ }^{33}$ See, for example, Grabowski, Cockburn and Long [2006], Grabowski [2008] and Federal Trade Commission [2009b].

${ }^{34}$ See, for example, Grabowski and Vernon [1992] and Drug Channels [2007a,b;2008a].

${ }^{35}$ Berndt and Newhouse [2010,2011]. 
${ }^{36}$ See The 2010-11 Economic Report on Retail and Specialty Pharmacies, www.PembrokeConsulting.com, Exhibit 2, p. 8, "Largest U.S. Pharmacies Ranked by Total Prescription Revenues, 2010E" (retail and mail order facilities).

${ }^{37}$ Berndt and Newhouse [2011].

${ }^{38}$ Frueh, Amur, Mummaneni et al. [2008].

39 Duggan, Healy and Scott Morton [2008].

${ }^{40}$ The six classes are anti-depressants, anti-psychotics, anti-convulsants, immunosuppressants, antiretrovirals and anti-neoplastic agents.

${ }^{41}$ Medicare also placed restrictions that the PDP must cover at least one drug in each Formulary Key Dug Type Class (FKDT), which is a finer category than therapeutic class typically containing only one or two brands; see Duggan and Scott Morton [2010] for details.

${ }^{42}$ WalMart [2010].

${ }^{43}$ For discussion and extensive references, see Drug Channels [2007a,b; 2008 a,b,c,d] and BerndtNewhouse [2010, 2011].

${ }^{44}$ But see Abelson and Singer [2011] for discussion of more recent develop0ments. 